\title{
A Case Study on Importance of Salt Recovery Plant in Textile Dyeing Industry
}

\author{
Israt Zerin*, Md. Rasel \\ Department of Textile Engineering, Southeast University, Dhaka, Bangladesh
}

Email address:

isratzrn@gmail.com (I. Zerin), raseltex888@gmail.com (Md. Rasel)

${ }^{*}$ Corresponding author

To cite this article:

Israt Zerin, Md. Rasel. A Case Study on Importance of Salt Recovery Plant in Textile Dyeing Industry. International Journal of Ecotoxicology and Ecobiology. Vol. 2, No. 4, 2017, pp. 166-171. doi: 10.11648/j.ijee.20170204.15

Received: November 2, 2017; Accepted: November 17, 2017; Published: December 13, 2017

\begin{abstract}
This study reveals recover salt from waste water as saline water, application of salty or saline water on dyeing of cotton fabric with reactive dyes and compare it with the samples dyed using ground water, compare the spectro photometric evaluation, color fastness to wash and rubbing. This study is done in the laboratory of Niagra Textiles Ltd. Bangladesh. It has been found that the results are satisfactory for the fabric dyed with both type of water.
\end{abstract}

Keywords: SRP, Dyeing, Waste Water, Saline Water, Fresh Water

\section{Introduction}

Salt Recovery Plant (SRP) is such a plant which is related with betterment of environment issue of dying sector as well as textile industry. In the last years, the rising systemization of industrial processes, the increasing use of waste water reuse and collection plants, urged to study new solutions and innovative technologies for fresh water recovery from dyebath and salt recovery from effluent water with active sludge biological system. Different projects have been done for recovering salt from dyed solution.

Textile industries mainly constitute large volume of fresh water and the effluent discharge are heavily polluted with dissolve solid, organic and color. The advance treatment technologies and processes, reducing concentration of the pollutants and also give scope for recovery and recycle of water and salt from effluents, which help conserve natural sources. [1]

The chemical treatments and advanced oxidation are mainly used to eliminate the dyes from textile effluents and do not bring any solutions to remove strong quantities of salt present in the complex effluent in textiles. [2] [3]

Enzymatic catalysis, coagulation/flocculation and nanofiltration processes are used for decolourization of the reconstituted textile effluent and nanofiltration seems to be an efficient process in colour removal of textile wastewater.
The obtained permeate can be reused in the dyeing process in the textile industry. [4] Reverse Osmosis has been successfully applied on a large scale throughout the world for the treatment of effluent and the polluted water. [5] [6]

Carrine, Phillipe, Michel and Francoise used nanofiltration and reverse osmosis step to recycle pure water and mineral salt in the dyeing processes and dyeing with the brines carried out with reactive dyes successively. [7]

The recycling of treated wastewater and zero wastewater discharge concept are found technically feasible and economically viable in the textile dyeing industries located in the area of Erode. [8]

It is possible to reuse some of the effluents after some simple and low cost treatment processes, without a negative impact on the product quality. The reuse of effluents will lead to water saving, reduced energy consumption, and lower effluent treatment costs. [9]

A study has been done on the applicability of a hybrid loose NF BMED process system for sustainable dye extraction, water and salt reuse from textile wastewater. The loose NF membrane (Sepro NF 6, Ultura) has an excellent diafiltration performance for the fractionation of (direct and reactive) dye/salt mixtures, allowing a free passage of salt ( $\mathrm{R}$ $\leq 2.2 \%)$ and high retention of dyes (>99.93\%). [10] A fluidized bed reactor for treatment of waste water is discovered and patented. [11]

In this study Chlorination, Ozonation, Reactor, Air 
Diffusion Tank, Flash Mixer, Pressure Sand Filter Feed (PSF), Ultra Filtration, Reverse Osmosis (RO) processes used for treatment of waste water after dyeing with reactive dye. After the treatment the saline water is used for dyeing fabric again and compared with the dyed fabric using ground water.

\section{Methodology}

Most of the salt concentration is contained in the dye bath, In this study we have followed SRP Plant, Niagra Textiles Ltd. It has been developed an innovative technology working directly on dye-bath discharge or waste water. It facilitates salt recovery reducing the quantity and allowing its reuse, isolating the considerable concentrate waste, treating it separately with the treatment plant.

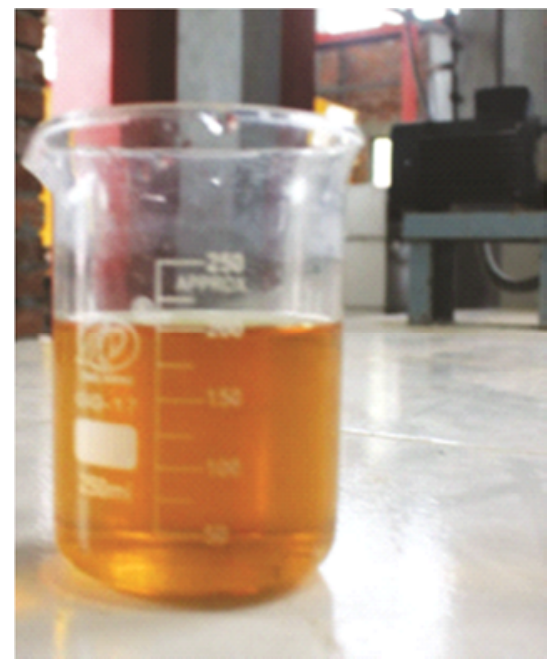

Figure 1. Salt Brine from SRP.

\subsection{Raw Materials: Chemical Has Been Used in This Plant} Are
a. Hydro chloric acid
b. Chlorine
c. Titanium (Ti)/Magnesium chloride
d. Poly aluminum chloride (PAC),
e. Ozone gas
f. Hydrogen

\subsection{Process Flow Chart of SRP}

Dye Bath Collection Tank $\rightarrow$ Chlorination $\rightarrow$ Ozonation $\rightarrow$ Reactor $\rightarrow$ Air Diffusion Tank $\rightarrow$ Flash Mixer $\rightarrow$ Pressure Sand Filter Feed (PSF) $\rightarrow$ Ultra Filtration $\rightarrow$ Reverse Osmosis (RO) $\rightarrow$ cleaning tank.

\subsubsection{Dye Bath Collection Tank}

At first the waste water comes from dye bath to dye bath collection tank. Only the water which contains $60 \mathrm{~g} / \mathrm{l}$ salt will be treated in salt recovery plant. This waste water having a PH about 10-11 while coming in dye bath and then Hydro chloric acid is added to reduce the $\mathrm{pH}$ level about 8 .

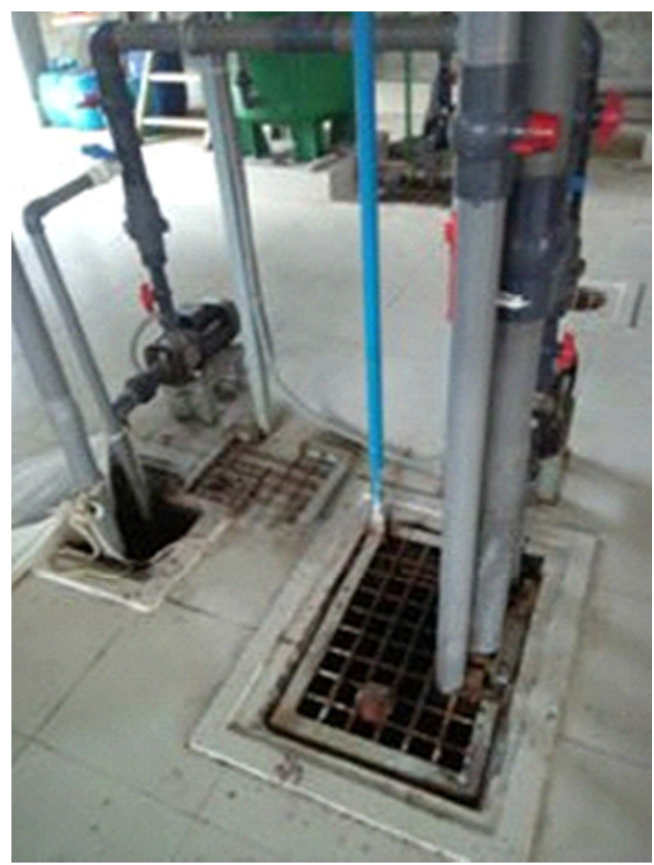

Figure 2. Collection Tank.

\subsubsection{Chlorination}

Waste water runs for the further process from dye bath and at a first stage chlorination has been done through the pipe. Water chlorination is the process of adding chlorine or hypochlorite to water. This method is used to kill certain bacteria and other microbes in tap water as chlorine is highly toxic and in this process water color is also reduced. When dissolved in water, chlorine converts to an equilibrium mixture of chlorine, hypochlorous acid ( $\mathrm{HOCl})$, and hydrochloric acid $(\mathrm{HCl})$. [1]

$$
\mathrm{Cl}_{2}+\mathrm{H}_{2} \mathrm{O} \rightleftharpoons \mathrm{HOCl}+\mathrm{HCl}
$$

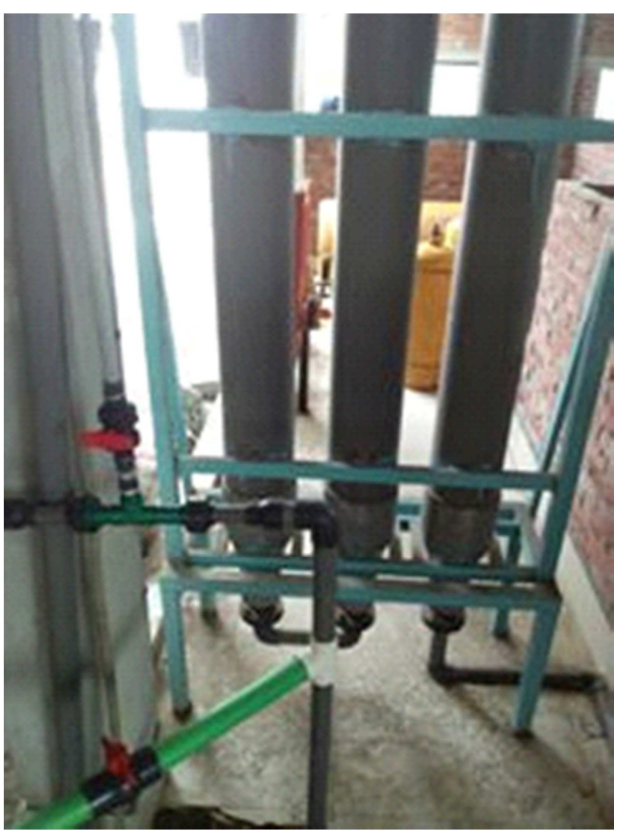

Figure 3. Chlorination Tank. 


\subsubsection{Ozonation}

After chlorination water has been reserved in Ozone tank. From there water goes to ozone tower and mixing with ozone gas and again back to the ozone tank. Ozone can eliminate a wide variety of inorganic, organic and microbiological problems and taste and odor problems. The microbiological agents include bacteria, viruses, and protozoans (such as Guardia and Cryptosporidium). Ozone is a powerful oxidant, leaves no residual harmful product, no sludge disposal problem and increases the DO content of wastewater which helps further in the degradation of residual pollutant. Therefore ozone finds use in treatment of all types of waste such as municipal waste water, industrial waste water, contaminated ground water, treatment of swimming pool water, treatment of paper industry waste water, dye industry waste water, removal of colour, treatment of gaseous effluent, treatment of cyanide waste water, treatment of heavy metals, elimination of phenolic compounds etc. and specially as strong disinfectant. [2]

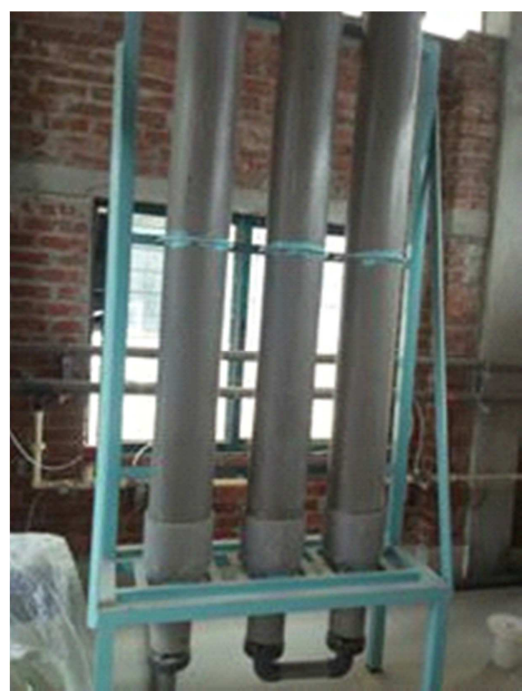

Figure 4. Ozonation Tank.

\subsubsection{Reactor}

After ozonation the water flows towards 6 boxes of reactors. The reactors are $\mathrm{Ti}$ and $\mathrm{Mcl}$. Which removes pathogens, color and wasted raw materials present in water and works for removing different types of toxic materials from water.

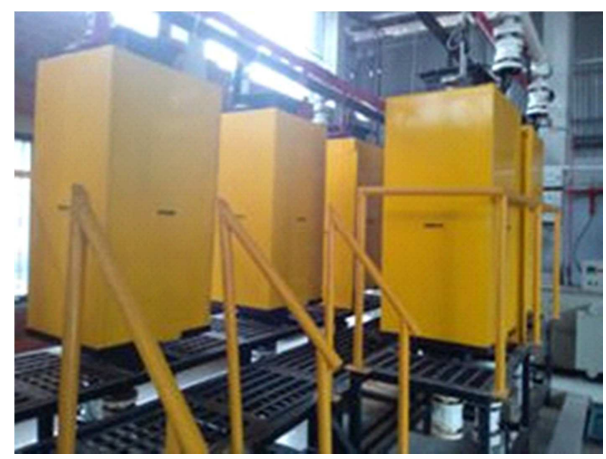

Figure 5. Reactor tank.

\subsubsection{Air Diffusion Tank}

After mixing with reactor the water goes to the air difftusiontank. Then air is passed to the air diffusion tank by blower Which increasing oxygen level in the water.

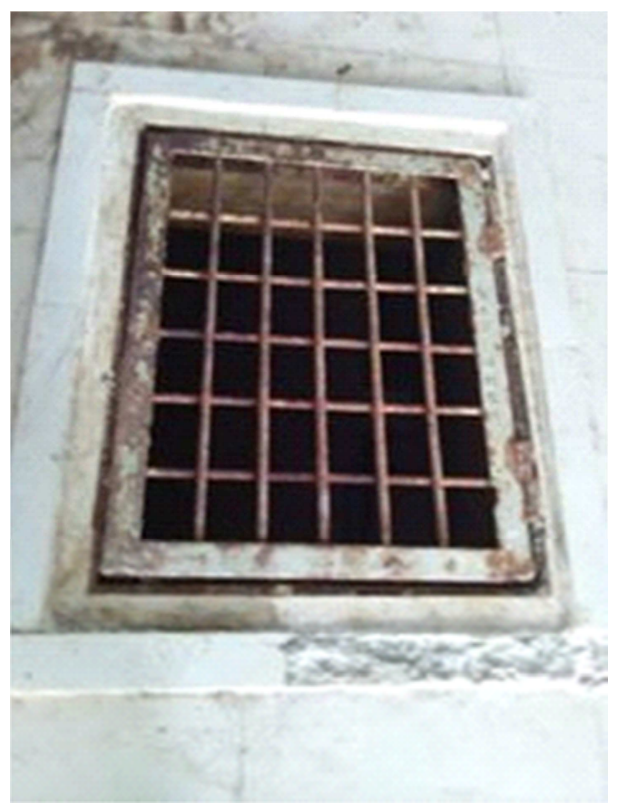

Figure 6. Air Diffusion Tank

\subsubsection{Flash Mixer}

Flash mixing is done in 4 tank. After air diffusion the water first reserved in $1^{\text {st }}$ tank. Then water goes to $2^{\text {nd }}$ tank and there mix with Poly Chloride (PC), Poly Aluminum Chloride (PAC). Which removes color and pathogen from water. After that the water enters into $3^{\text {rd }}$ tank and mix with polymer. And then water flows towards the $4^{\text {th }}$ tank and there separation of water and sludge is done. The $4^{\text {th }}$ tank also called as clarifier tank. Titanium metal contains on surface layer of titanium oxide that prevents through chemical reactions. When the layer is damaged it is usually restored rapidly. This not only occurs when it comes in contact with air but also in contact with water. This reaction forms both titanium oxide and highly flammable hydrogen gas according to the following reaction mechanism:

$$
\mathrm{Ti}(\mathrm{s})+2 \mathrm{H}_{2} \mathrm{O}(\mathrm{g}) \square \mathrm{TiO}_{2}(\mathrm{~s})+2 \mathrm{H}_{2}(\mathrm{~g})
$$

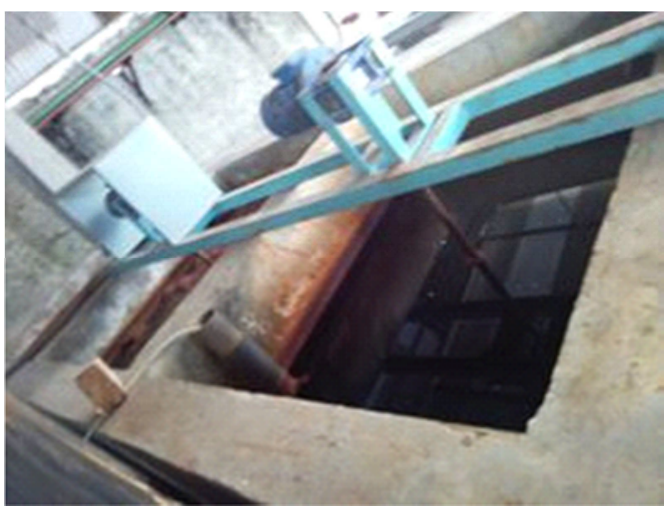

Figure 7. Flash Mixer. 


\subsubsection{Pressure Sand Filter Feed (PSF)}

From Clarifier tank water goes to the PSF tank where water get recycled and get filtered and then goes for another process through the pipe.

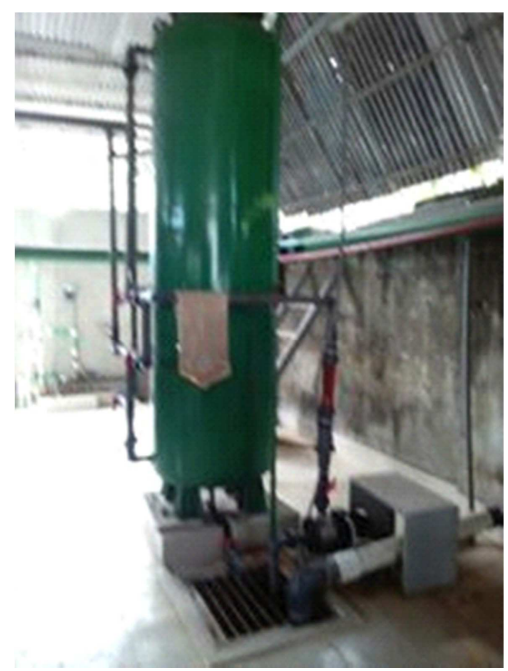

Figure 8. Pressure Sand Filter Feed(PSF).

\subsubsection{Ultra Filtration}

From PSF Feed the water comes to the ultra filtration feed tank. Feed tank water goes to ultra filtration tower. There pathogens are removed and water get filtered and recycled also.

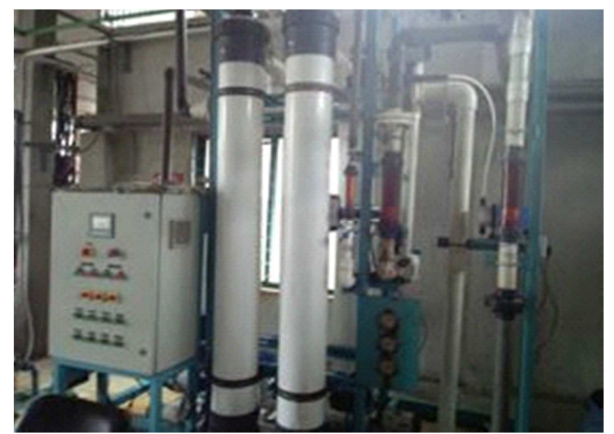

Figure 9. Ultra Filtration tank.

\subsubsection{Reverse Osmosis (RO)}

This is the last stage of Salt Recovery Plant. After ultra filtration water goes to the two RO feed tank. From RO feed tank water flows toward RO tower. In this process high air pressure is provided by a motor to the RO tank and water recycled and creates saline water and fresh water.

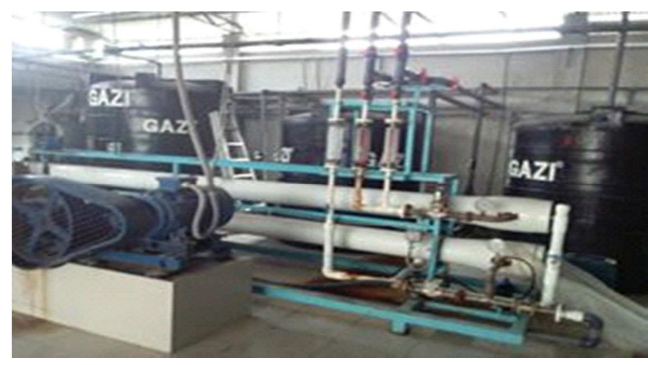

Figure 10. Reverse Osmosis (RO).

\subsubsection{Cleaning Tank}

When ultra filtration tower and reverse osmosis tower deposits dirt, this time cleaning is done by chlorine gas in cleaning tank. This process is held after every twenty days.

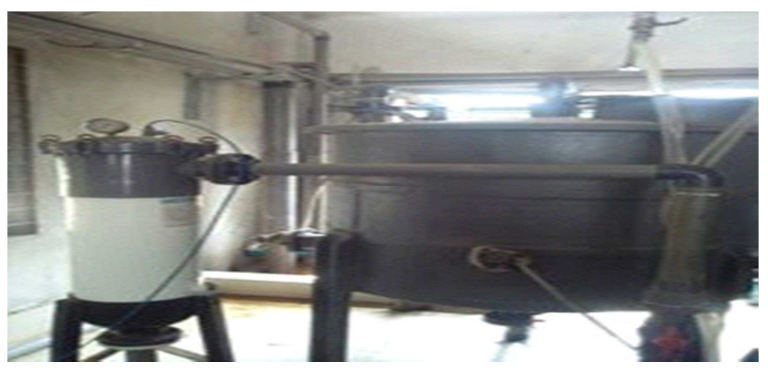

Figure 11. Cleaning tank.

\subsection{Dyeing of Cotton Fabric Using Saline Water from SRP and Ground Water}

Cotton fabric dyed with reactive dyes with ground water and saline water from SRP. Gluber Salt is added according to the calculation of extra salt needed prior to the salt content remain in the saline water.

\subsubsection{Recipe}

Jinjipi Super yellow- $0.18 \%$

Jinjipi Deep Red CD-2.3\%

Dychufix Navy blue GG-0.15\%

Gluber salt- $60 \mathrm{~g} / \mathrm{L}$

Soda ash $-2.25 \mathrm{~g} / \mathrm{L}$

Levelling Agent- $0.6 \mathrm{~g} / \mathrm{L}$

Sequestering Agent- $0.5 \mathrm{~g} / \mathrm{L}$

pH 10-11

Time 60min

Temparature $60^{\circ} \mathrm{C}$

Liquor ratio 1:6

\subsubsection{Comparison on Shade Variation}

The shade difference of the samples has been evaluated by Verivide light box.

\subsubsection{Spectrophotometric Evaluation of Dyed Samples}

Color co-ordinates values of dyed samples were compared by using spectrophotometer "Spectro 600" (Spectro 600).

\subsubsection{Color Fastness to Wash}

Washing fastness of dyed samples was tested according to ISO $105: \mathrm{CO} 3$ method at $60^{\circ} \mathrm{C}$ for 30 minutes.

\subsubsection{Color Fastness to Rubbing}

This test is designed to determine the degree of color which may be transferred from the surface of a colored fabric to a specific test cloth for rubbing (dry and wet), Method: ISO $105 / 12$ and M/c Name: Crock master has been used for rubbing test.

\subsubsection{Salt Recovery Calculation}

Salt recovery prportion is calculated according to the capacity of the plant and expressed as percentage. 


\section{Result \& Discussions}

\subsection{Comparison on shade\%}

Table 1. Samples dyed with ground water and saline water from SRP.

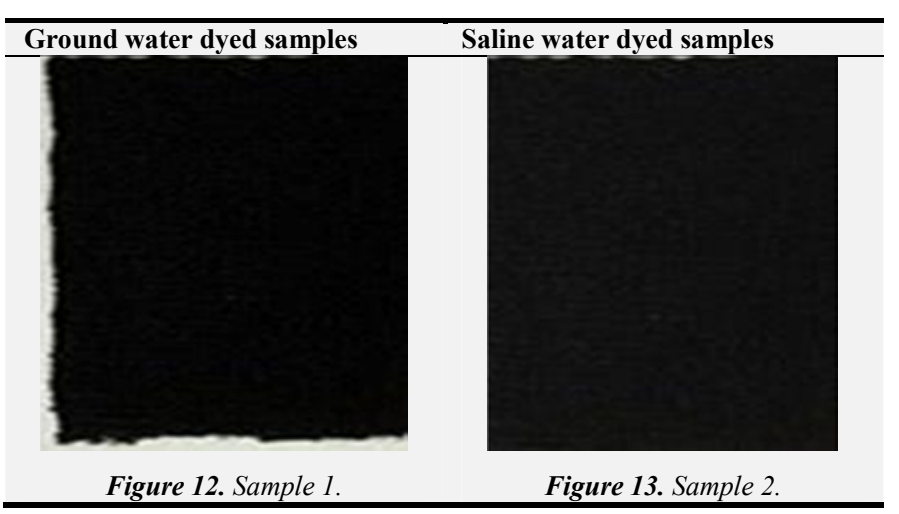

\subsection{Spectrophotometric Evaluation}

The Light sources D65 and D55 are used for the spectrophotometric evaluation. The lightness (DL), Saturation (DC) and Tone (DH), CIE lab value for references (Da and $\mathrm{Db}$ ), Total color deviations (DE) are evaluated between the ground water dyed cotton samples and saline water dyed samples.

From the Table 2, the spectrophotometric values under different light sources of CMC (Color matching committee) it is seen that; ground water and saline water dyed samples DE value lies below 1, which is the desired outcome of this work. The DE values for the samples under different light sources of spectrophotometer D65 and D55, the samples are passed on evaluation as all the values are less than 1 .

Table 1 show the shade of each samples dyed with ground water and saline water from SRP.

Table 2. Spectrophotometric Evaluation of Dyed Samples.

\begin{tabular}{lllllllll}
\hline \multirow{2}{*}{ Standard } & \multirow{2}{*}{ Sample } & \multirow{2}{*}{ Illum./obs } & $\begin{array}{l}\text { Lightness } \\
\text { (DL) }\end{array}$ & $\begin{array}{l}\text { Saturation } \\
\text { (Dc) }\end{array}$ & $\begin{array}{l}\text { Tone } \\
\text { (DH) }\end{array}$ & $\begin{array}{l}\text { CIE Lab value for } \\
\text { ref.Da }\end{array}$ & $\begin{array}{l}\text { CIE Lab value for } \\
\text { ref.Db }\end{array}$ & $\begin{array}{l}\text { Total color deviation } \\
\text { DE }\end{array}$ \\
\hline \multirow{2}{*}{ Sample 1 } & \multirow{2}{*}{ Sample 2 } & D65 10 Deg & 0.19 & 0.16 & 0.43 & -0.20 & 0.25 \\
& D55 10 Deg & 0.18 & 0.08 & 0.47 & -0.16 & 0.50 \\
\hline
\end{tabular}

\subsection{Color Fastness to Wash}

Table 3 shows that the change in color due to wash on reactive dyed ground and saline water dyed samples. The wash fastness rating in terms of ground water and saline water dyed samples 1 and sample 2 is ' 5 '. It indicates that the results are almost same and there is no significant difference for the samples.

Table 3. Color fastness to wash.

\begin{tabular}{llll}
\hline Samples & WTP water dyed samples & Samples & Saline water dyed samples \\
\hline Sample-1 & 5 & Sample-2 & 5 \\
\hline
\end{tabular}

\subsection{Color Fastness to Rubbing}

Table 4 shows the results of rubbing fastness of the samples no 1 and 2 . In case of sample no. 1 for the dry and wet rubbing fastness rating is 4 and 3. For sample 2 dry and wet rubbing fastness rating is 4 and $3 / 4$. The rubbing fastness result may reveal that saline water dyed samples have significant result compared to ground water dyed sample.

Table 4. Results of Rubbing Fastness.

\begin{tabular}{|c|c|c|c|c|c|}
\hline \multirow{2}{*}{ Samples } & \multicolumn{2}{|c|}{ Ground water dyed samples } & \multirow{2}{*}{ Samples } & \multicolumn{2}{|c|}{ Saline water dyed samples } \\
\hline & Dry & Wet & & Dry & Wet \\
\hline Sample-1 & 4 & 3 & Sample-2 & 4 & $3 / 4$ \\
\hline
\end{tabular}

\subsection{Salt Recovery Calculation}

Effluent Plant capacity $=75 \mathrm{~m} 3 /$ day $=3.5 \mathrm{~m} 3 / \mathrm{hr}$

Saline water production capacity $=35 \mathrm{~m} 3 / \mathrm{day}=70 \mathrm{~g} / 1$

In this factory, As per recipe gluber salt $=80 \mathrm{~g} / \mathrm{l}$ needed for dyeing $1000 \mathrm{~kg}$ fabric

$\mathrm{M}: \mathrm{L}=1: 6$

$$
\text { Total salt require }=6 * 80=480 \mathrm{~kg}
$$

With saline water salt covered $=(1000 * 6) 70 / 1000=420 \mathrm{~kg}$

$$
\text { salt save }=(480-420)=60 \mathrm{~kg}
$$

Daily, average gluber salt require $=7000 \mathrm{~kg}$

Saline water production per day $=35000 \operatorname{ltr}(70 / 100)$

So salt recovery per day $=2450 \mathrm{~kg}$

Total salt recovery $=(2450 / 7000) * 100 \%=35 \%$

So, $35 \%$ of total salt used is recovered by using salt recovery plant in Niagra Textiles Limited.

\section{Conclusion}

Now a day's gradual increasing use of deep water in industries especially in textile industries which is a big threat 
for our ecological balance \& environment. So considering the situation many textile industries of all over the world should be implemented this plant because of the welfare of our environment and maintain a hygienic nature by blowing out toxic-free water from their industries waste by recycling waste into fresh water \& saline water.

After implementation of this plant Niagra Textiles Limited can use up to $60 \%$ water which is wasted $\&$ capable of saving a huge amount of deep water for textile dyeing which reduce cost of dyeing also. Saline water using in dyeing and fresh water used for making steam in boiler. The fresh water which has no toxication but get out pathogens from the plant can be used for making steam in boiler or car washing and different purposes without drinking. Through this Plant it has been reduced huge effect on sea water where is less effect on environment maintaining a healthy ecological balance.

\section{Acknowledgements}

We would like to thank Shipon Sutradhar and Mahfuzur Rahman the final year students of Department of Textile Engineering, Southeast University for collecting the dyeing materials used in this study. Special thanks to Mr. Arifur Rahaman Liton for helping at Salt recovery Plant operations at Niagra textiles Limited.

\section{References}

[1] Shunji Nakagawara, Takeshi Goto, Masayuki Nara, Youichi Ozaqa, Kunimoto Hotta and Yoji Arata (1998). "Spectroscopic Characterization and the $\mathrm{pH}$ Dependence of Bactericidal Activity of the Aqueous Chlorine Solution". Analytical Sciences. 14 (4): 691-698. doi:10.2116/analsci.14.691.

[2] K. Upadhyay, J. K. Srivastava, Application of Ozone in the treatment of industrial an municipal waste water, Jr. of Industrial Pollution Control 21 (2)(2005) pp 235-245.

[3] B Marrot, N Roche, Waste water treatment and reuse in textiles industries-a review, Res Adv, in water research 3, $2002,41-53$.
[4] Imen Khouni, Benoît Marrot, Philippe Moulin, Decolourization of the reconstituted textile effluent by different process treatments: Enzymatic catalysis, coagulation/flocculation and nanofiltration processes, Desalination 268(1-3) · March 2011, DOI: 10.1016/j.desal.2010.09.046

[5] A. B. M. Foisal, S. D. Saha, A. K. M. Shafayet Khan, Md. Abdullah al Noman (2016), Reuse Of Dye House Waste Water By Reverse Osmosis Process, Journal of Science \& Engineering (SEUJSE) ISSN 1999-1630, volume 10, No. 2, p70-74.

[6] B. L. Pangarkar, M. G. Sane, M. Guddad, Reverse Osmosis and Membrane Distillation for Desalination of Groundwater: A Review, ISRN Materials Science Volume 2011, Article ID 523124, 9 pages doi:10.5402/2011/523124

[7] Carine Alligre, Philippe Moulin, Michel Maisseu, Francoise Charbit, Treatment and valorization of the Textile Waste water.

[8] M. Ramesh Kumar, C. V. Koushik, K. Saravanan, Textile wastewater treatment using reverse osmosis and SDI, Elixir International Journal, Elixir Chem. Engg. 54A (2013) 1271312717

[9] Nazan Erdumlu, Bulent Ozipek, Goncagul Yilmaz, Ziynet Topatan, Reuse of effluentwaterobtained in different textile finishing processes, AUTEX Research Journal, Vol. 12, No1, March 2012.

[10] Jiuyang Lin, Wenyuan Ye, Jie Huang, Borrego Ricard, Marian-Cornel Baltaru, Benjamin Greydanus, Stefan Balta, Jiangnan Shen, Maria Vlad, Arcadio Sotto, Patricia Luis, and Bart Van der Bruggen, Toward Resource Recovery from Textile Wastewater: Dye Extraction, Water and Base/Acid Regeneration Using a Hybrid NF-BMED Proces, ACS Sustainable Chem. Eng., 2015, 3 (9), pp 1993-2001, DOI: 10.1021/acssuschemeng.5b00234

[11] Ganesan Sekaran, Sekar Karthikeyan, Ramasamy Boopathy, Asit Baran Mandal, A fluidized bed reactor for treatment of waste water, Patent WO2014037959 A1, PCT/IN2013/000069, Publication date:13.03.2014

[12] K. A Goff, Textile Wastes, Res. J. of water pollution control federation, 63(1991) p 451-462. 